\title{
Pengaruh Profitabilitas Terhadap Struktur Keuangan
}

Program Studi Manajemen Fakultas Ekonomi dan Bisnis
Universitas Trunojoyo Madura

\section{PENDAHULUAN}

Perusahaan sebagai entitas ekonomi lazimnya memiliki tujuan jangka

pendek dan jangka panjang. Dalam jangka pendek perusahaan bertujuan memperoleh laba secara maksimal dengan menggunakan sumberdaya yang ada, sementara tujuan utama perusahaan dalam jangka panjang adalah memaksimalkan nilai perusahaan. Rendahnya kualitas laba akan dapat membuat kesalahan pembuatan keputusan para pemakainya seperti investor dan kreditor, sehingga nilai perusahaan akan berkurang (Siallagan dan Machfoedz dalam chandra parni hemastuti, 2014: 2). Untuk mencapai nilai perusahaan umumnya para pemodal menyerahkan pengelolaannya 


\section{Pengaruh Profitabilitas Terhadap Struktur,... Monica Budi Rahayu}

kepada para profesional.(chandra Pami Hemastuti, 2014: 1-2)

Profitabilitas adalah kemampuan perusahaan untuk menghasilkan laba. Laba sering kali menjadi ukuran kinerja perusahaan, dimana ketika perusahaan memiliki laba yang tinggi berarti dapat disimpulkan bahwa kinerja perusahaan tersebut baik dan juga sebaliknya (Ketut Gunawan, Nyoman Ari Surya Darmawan, dan Gusti Ayu Purnamawati, 2015: 2). Profitabilitas juga merupakan gambaran dari kinerja manajemen dalam mengelola perusahaan (Petronila dan Muklasin dalam Elyzabet Indrawati Marpaung, 2010: ). Ukuran profitabilitas digunakan untuk mengukur kemampuan perusahaan memperoleh laba pada tingkat penjualan, aset, dan modal saham tertentu. Laba merupakan hasil bersih aktivitas operasi usaha dalam periode tertentu yang dinyatakan dalam istilah keuangan. Profitabilitas selain digunakan untuk mengukur kemampuan perusahaan dalam menghasilkan laba juga untuk mengetahui efektivitas perusahaan dalam mengelola sumber-sumber yang dimilikinya.

Menurut Weston dan Copeland (1999) struktur keuangan adalah cara bagaimana perusahaan membiayai aktivanya. Struktur METODE

Dalam artikel ilmiah ini penulis menggunakan studi literatur. pengertian

Studi literatur secara garis besar adalah serangkaian kegiatan yang berkenaan dengan metode pengumpulan data pustaka, membaca dan mencatat, serta mengolah bahan studi literatur. Jenis data yang dipakai dalam studi literatur ini adalah data sekunder. Data sekunder yang dipergunakan dalam studi literatur ini adalah data profitabilitas dan struktur keuangan yang diperoleh dari jurnal studi literatur ilmiah.

\section{PEMBAHASAN}

Profitabilitas mencerminkan kemampuan memperoleh laba dalam

hubungannya dengan penjualan, modal sendiri maupun total aset. Profitabilitas merupakan daya tarik utama bagi pemilik perusahaan karena profitabilitas merupakan hasil yang diperoleh melalui usaha manajemen atas dana yang diinvestasikan para pemegang saham dan juga mencerminkan pembagian laba yang menjadi haknya yaitu seberapa banyak yang diinvestasikan kembali dan seberapa banyak yang dibayarkan sebagai dividen tunai ataupun keuangan dapat dilihat pada seluruh sisi kanan neraca. Ini terdiri dari hutang jangka pendek, hutang jangka panjang, dan modal pemegang saham. Sedangkan Struktur modal atau permodalan perusahaan adalah pembiayaan permanen yang terdiri dari hutang jangka panjang, saham preferen, dan modal pemegang saham. Jadi struktur modal suatu perusahaan hanya merupakan sebagian dari struktur pembiayaannya. (Weston dan Copeland (1999) dalam Elyzabet Indrawati Marpaung, 2010: 4)

Dari latar belakang masalah yang diuraikan di atas dapat dirumuskan sebuah masalah dalam artikel ilmiah ini yaitu profitabilitas terhadap struktur keuangan. Tujuan dari artikel ilmiah ini adalah untuk mengetahui pengaruh profitabilitas terhadap struktur keuangan. Manfaat artikel ilmiah ini yang diharapkan: bagi penulis dapat memenuhi tugas ujian akhir semester matakuliah metodologi studi literatur yang diampu oleh bapak Dr. Mohammad Arief, SE., MM. Bagi pembaca yaitu dapat dijadikan sebagai referensi pembaca tentang profitabilitas terhadap struktur keuangan . selain itu artikel ilmiah ini diharapkan dapat menjadi pembanding atau bahan referensi tentang pembuatan artikel ilmiah bagi pembuatan artikel ilmiah yang baru.

dividen saham kepada mereka.(chandra Pami Hemastuti, 2014: 2)

Tujuan profitabilitas berkaitan dengan kemampuan perusahaan untuk mendapatkan laba yang tinggi sehingga pemodal dan pemegang saham akan meneruskan untuk menyediakan modal bagi perusahaan.(chandra Pami

Hemastuti, 2014: 3). Manfaat rasio profitabilitas tidak terbatas hanya pada pemilik usaha atau manajemen saja, tetapi juga bagi pihak eksternal perusahaan, terutama pihak - pihak yang memiliki hubungan atau kepentingan dengan perusahaan. Didalam penulisan artikel ilmiah ini, alat ukur dalam mengukur rasio profitabilitas adalah dengan menggunakan return on equity (ROE). ROE adalah rasio laba bersih terhadap ekuitas saham biasa, yang mengukur tingkat pengembalian atas investasi dari pemegang saham biasa. Naiknya ROE dari tahun ke tahun pada perusahaan berarti terjadi adanya kenaikan laba 


\section{Jurnal Studi Manajemen dan Bisnis}

Vol. 5 (2) 2018

bersih dari perusahaan yang bersangkutan.( chandra Pami Hemastuti, 2014: 4). Rumus ROE dapat dihitung sebagai berikut: (Umi Mardiyati, Gatot Nazir Ahmad dan Ria Putri, 2012: 9)

Perusahaan dengan tingkat profitabilitas yang tinggi mengindikasikan

bahwa perusahaan tersebut mampu menjalankan usahanya dengan baik sehingga dapat mempertahankan kelangsungan hidupnya. Dengan kata lain, semakin tinggi tingkat profitabilitas maka semakin rendah pula kemungkinan pemberian opini audit going concern oleh auditor. Sebaliknya, perusahaan yang memiliki tingkat profitabilitas rendah maka cenderung akan mendapatkan opini audit going concern (Komalasari, 2003).

Bagi setiap perusahaan, keputusan dalam pemilihan sumber dana merupakan hal yang penting sebab hal tersebut akan mempengaruhi struktur keuangan perusahaan, yang akhirnya juga akan mempengaruhi kinerja perusahaan. Untuk dapat menciptakan struktur keuangan yang menunjang kinerja dan memaksimalkan laba bagi perusahaan, maka perlu diperhatikan variabel-varibel yang mempengaruhi struktur keuangan. Menurut Weston dan Copeland (1999) beberapa variabel yang mempengaruhi struktur keuangan adalah (1) tingkat pertumbuhan penjualan; (2) stabilitas penjualan;

karakteristik industri; (4) struktur aktiva; (5) sikap manajemen; dan (6) sikap pemberi pinjaman terhadap perusahaan dan industri. (Elyzabet Indrawati Marpaung, 2010: 2)

Berdasarkan teori yang dikemukakan oleh Brigham dan Houston (2001:

39) profitabilitas merupakan variabel yang mempengaruhi struktur keuangan atau dapat dikatakan bahwa profitabilitas mempunyai pengaruh yang signifikan terhadap struktur keuangan. Studi literatur empiris yang dilakukan oleh Hasa Nurrohim KP (2008) dalam Elyzabet Indrawati Marpaung, 2010: 11) menunjukkan bahwa profitabilitas merupakan salah satu variabel yang berpengaruh terhadap struktur keuangan. Dalam studi literatur ini kemampulabaan diwakili oleh Return On Assets (ROA), yaitu dengan membandingkan laba bersih dengan total aktiva perusahaan. Menurut Weston dan Brigham dalam Elyzabet Indrawati Marpaung, 2010: 11) perusahaan dengan tingkat return on asset yang tinggi, umumnya menggunakan hutang dalam jumlah yang relatif sedikit. Hal ini disebabkan return on asset yang tinggi tersebut, memungkinkan perusahaan melakukan permodalan dengan laba ditahan saja. (
Elyzabet Indrawati Marpaung, 2010: 11)

Variabel dependen dalam studi literatur ini adalah Struktur Keuangan (SK) diukur dengan membandingkan total hutang dengan total aktiva.

Didalam struktur keuangan terdapat konsep penting yaitu faktor leverage yang merupakan rasio antara nilai buku seluruh utang terhadap total aktiva. Leverage factor $30 \%$ berarti bahwa bahwa perusahaan menggunakan modal pinjaman sebesar $30 \%$ dari total assets perusahaan. Salah satu aspek yang harus dipertimbangkan adalah semakin besar leverage factor berarti semakin besar beban tetap(bunga) yang harus dibayarkan kepada keditur sehingga semakin kecil bagian laba dari pemegang saham biasa(gitosudarmo 1989 dalam eko supriyanto dan falikhatun, 2008: 3)

Penggunaan utang yang semakin besar didalam struktur keuangan, selain akan menurunkan bagian laba dari pemegang saham biasa,juga akan berakibat fatal bagi perusahaan yaitu timbulnya distress. Menurut kusuma dan roekhudin

2014 dalam eko supriyanto dan falikhatun, 2008: 3) financial distress merupakan suatu kondisi yang menggambarkan perusahaan mengalami kesulitan keuangan dan terancam pada kebangkrutan. (eko supriyanto dan falikhatun, 2008: 3)

\section{SIMPULAN DAN SARAN}

Berdasarkan penulisan artikel ilmiah di atas dapat ditarik kesimpulan

bahwa: profitabilitas merupakan variabel yang mempengaruhi struktur keuangan atau dapat dikatakan bahwa profitabilitas mempunyai pengaruh yang signifikan terhadap struktur keuangan. Studi literatur empiris yang dilakukan oleh Hasa Nurrohim KP (2008) menunjukkan bahwa profitabilitas merupakan salah satu variabel yang berpengaruh terhadap struktur keuangan. Dalam studi literatur ini kemampulabaan diwakili oleh Return On Assets (ROA), yaitu dengan membandingkan laba bersih dengan total aktiva perusahaan. Menurut Weston dan Brigham dalam Kesuma (2009 :39) perusahaan dengan tingkat return on asset yang tinggi, umumnya menggunakan hutang dalam jumlah yang relatif sedikit. Hal ini disebabkan return on asset yang tinggi tersebut, memungkinkan perusahaan melakukan permodalan dengan laba ditahan saja. Untuk penulisan artikel ilmiah selanjutnya diharapkan untuk menambah variabel-variabel yang belum tercantum dalam penulisan artikel ilmiah ini. 


\section{Pengaruh Profitabilitas Terhadap Struktur,... Monica Budi Rahayu}

\section{DAFTAR PUSTAKA}

Margaretha, Farah Dan Letty. 2017. Faktor-Faktor Yang Memengaruhi Kinerja

Keuangan Perbankan Indonesia. Manajemen Keuangan.Vol. 6. No. 2. Hal: 84-96.

Amertha, Indra Satya Prasavita. 2013. Pengaruh Return On Asset Pada Praktik Manajemen Laba Dengan Moderasi Corporate Governance. E-Jurnal Akuntansi Universitas Udayana. Vol. 4. No. 2. Hal: 373-387.

Ariyani, Ni Nyoman Trisna Dewi dan Budiartha, Ketut. 2014. Pengaruh

Profitabilitas, Ukuran Perusahaan, Kompleksitas Operasi Perusahaan

Dan Reputasi Kap Terhadap Audit Report Lag Pada Perusahaan

Manufaktur. E-Jurnal Akuntansi Universitas Udayana. Vol. 8. No. 2. Hal:

217-230.

Astriani, Eno Fuji. Pengaruh Kepemilikan Manajerial, Leverage, Profitabilitas, Ukuran Perusahaan Daninvestment Opportunity Set Terhadap Nilai Perusahaan. Hal: 1-25.

Barus, Andreani Caroline dan Leliani. 2013. Analisis Faktor-Faktor Yang Mempengaruhi Profitabilitas Pada Perusahaan Manufaktur Yang Terdaftar Di Bursa Efek Indonesia. Jurnal Wira Ekonomi Mikroskil. Vol

3. No. 02. Hal: 111-121.

Bestivano, Wildham. Pengaruh Ukuran Perusahaan, Umur Perusahaan, Profitabilitas, Dan Leverage Terhadap Perataan Laba Pada Perusahaan Yang Terdaftar Di Bei. Hal: 1-25.

Deitiana,Tita. 2011. Pengaruh Rasio Keuangan, Pertumbuhan Penjualan Dan Dividen Terhadap Harga Saham. Jurnal Bis Nis Dan Akuntansi. Vol. 13. No. 1. Hal: 57 - 66.

Dewi, Ayu Sri Mahatma dan Ary, Wirajaya. 2013. Pengaruh Struktur Modal, Profitabilitas Dan Ukuran Perusahaan Pada Nilai Perusahaan. EJurnal Akuntansi Universitas Udayana. Vol. 4. No. 2. Hal: 358-372.

Gunawan, Ade Dan Wahyuni, Sri Fitri. 2013. Pengaruh Rasio Keuangan Terhadap Pertumbuhan Laba Pada Perusahaan Perdagangan Di Indonesia. Jurnal Manajemen \& Bisnis. Vol. 13. No. 01. Hal: 63-84.

Gunawan, Ketut. Darmawan, Nyoman Ari Surya dan Purnamawati, Gusti Ayu.

2015. Pengaruh Ukuran Perusahaan, Profitabilitas, Dan Leverage Terhadap Manajemen Laba Pada Perusahaan Manufaktur Yang Terdaftar Di Bursa Efek Indonesia (Bei). Journal S1 Ak Universitas Pendidikan Ganesha Jurusan
Akuntansi Program S1. Vol. 03. No. 01. Hal: 110.

Hemastuti, Candra Pami. 2014. Pengaruh Profitabilitas, Kebijakan Dividen, Kebijakan Hutang, Keputusan Investasi Dan Kepemilikan Insider Terhadap Nilai Perusahaan. Jurnal Ilmu \& Riset Akuntansi. Vol. 3 No. 4. Hal: 1-15.

Herawati, Titin. Pengaruh Kebijakan dividen, Kebijakan Hutang Dan

Profitabilitas Terhadap Nilai Perusahaan. Hal: 1-18. Insiroh, Lusia. 2014. Pengaruh Profitabilitas, Ukuran Perusahaan, Pertumbuhan Aset, Dan Struktur Aset Terhadap Struktur Modal. Jurnal Ilmu Manajemen. Vo. 2. No. 3.

Kristiana, Ira. 2012. Pengaruh Ukuran Perusahaan, Profitabilitas, Likuiditas, Pertumbuhanperusahaan Terhadap Opini Audit Going Concern Pada Perusahaan Manufaktur Yang Terdaftar Di Bursa Efek Indonesia (Bei). Berkala Ilmiah Mahasiswa Akuntansi. Vol. 1. No. 1. Hal: 47-51.

Mardiyati, Umi. Ahmad Gatot, Nazir dan Putri, Ria. 2012. Pengaruh Kebijakan Dividen, Kebijakan Hutang Dan Profitabilitas Terhadap Nilai Perusahaan Manufaktur Yang Terdaftar Di Bursa Efek Indonesia (Bei) Periode 2005-

2010. Jurnal Riset Manajemen Sains Indonesia (JRMSI). Vol. 3. No. 1. Hal: 1-17.

Toding, Merlina dan Made Gede, Wirakusuma. 2013. Faktor-Faktor Yang Memengaruhi Ketepatwaktuan Penyampaian Laporan Keuangan. E-Jurnal Akuntansi Universitas Udayana. Vol. 3. No. 3. Hal: 15-31.

Ustiani, Nila. Pengaruh Struktur Modal, Kepemilikan Manajerial, Keputusan Investasi, Kebijakan Dividen, Keputusan Pendanaan Dan Profitabilitas Terhadap Nilai Perusahaan. Hal: 1-20.

Widowati, Sari Ayu dan Suryono Bambang. 2015. Pengaruh Rasio Keuangan Terhadap Profitabilitas Perbankan Di Indonesia. Jurnal Ilmu \& Riset Akuntansi. Vol. 4. No. 6. Hal: 115.

Marpaung, Elyzabet Indrawati. 2010. Pengaruh Pertumbuhan Penjualan, Leverage Operasi, dan Profitabilitas terhadap Struktur Keuangan. Jurnal Akuntansi. Vol. 2. No.1. Hal: 1-14.

Munawaroh, Aisyatul dan Priyadi, Maswar Patuh. 2014. Pengaruh Profitabilitas Terhadap Nilai Perusahaan Dengan Corporate Social Responsibilty Sebagai Variabel Moderating. Jurnal Ilmu \& Riset Akuntansi. Vol. 3. No. 


\section{Jurnal Studi Manajemen dan Bisnis \\ Vol. 5 (2) 2018}

4. Hal: 1-17.

Nasir, Azwir. Kurnia, Pipin Dan Hakri, Teguh Dheki. 2013. Pengaruh Kepemilikan Manajerial, Leverage, Profitabilitas, Ukuran, Dan Umur Perusahaan Terhadap Pengungkapan Informasi Pertanggungjawaban Sosial Perusahaan Pada Perusahaan Food And Beverage Yang Terdaftar Di Bei. Jurnal Ekonomi. Vol. 21. No. 4. Hal: 1-4.

Nugroho, Agus Sumarnadi. 2012. Pengaruh Karakteristik Perusahaan Terhadap Tingkat Keluasan Pengungkapan Laporan Keuangan Pada Sektor Industri Makanan Da N Minuman Yang Terdaftar Di Bursa Efek Indonesia. Jurnal Ilmu \& Riset Akuntansi. Vol. 1. No. 12. Hal: 1-27.

Prasetyorini, Bhekti Fitri. 2013. Pengaruh Ukuran Perusahaan, Leverage, Price Earning Ratio Dan Profitabilitas Terhadap Nilai Perusahaan. Jurnal Imu Manajemen. Vol. 1. No. 1. Hal: 183196.

Putri, Meidera Elsa Dwi. 2012. Pengaruh Profitabilitas,Struktur Aktiva dan Ukuran Perusahaan terhadap Struktur Modal pada Perusahaan Manufaktur Sektor Industri Makanan dan Minuman yang Terdaftar di

Bursa Efek Indonesia(BEI). Jurnal Manajemen. Vol. 01. No. 01. Hal: 1-10. Rahayu, Eka Ayu Dan Susilowibowo, Joni. 2014. Pengaruh Perputaran Kas, Perputaran Piutang Dan Perputaran Persediaan Terhadap Profitabilitas Perusahaan Manufaktur. Jurnal Ilmu Manajemen. Vol. 2. No. 4. Hal:
1444-1455.

Sangkala, H. Abd. Azis. Analisis Kinerja Keuangan Berdasarkan Rasio Profitabilitas Pada Perusahaan Pabrik Roti Tony Bakery Pare-Pare. Jurnal Ekonomi Balance Fekon Unismuh Makassar. Hal: 1-19.

Santoso, Clairene E.E. 2013. Perputaran Modal Kerja Dan Perputaran Piutang Pengaruhnya Terhadap Profitabilitas Pada Pt. Pegadaian (Persero). Jurnal EMBA. Vol. 1. No.4. Hal: 1581- 1590.

Sudarmadji, Ardi Murdoko Dan Sularto, Lana. 2007. Pengaruh Ukuran Perusahaan, Profitabilitas, Leverage, Dan Tipe Kepemilikan Perusahaanterhadap Luas Voluntary Disclosure Laporan Keuangan Tahunan. Vol. 2. Hal: 18582559.

Sufiana, Nina dan Ni Ketut, Purnawati. Pengaruh Perputaran Kas, Perputaran

Piutang Dan Perputaran Persediaan Terhadap Profitabilitas. Hal: 451-

467.

Supriyanto, Eko Dan Falikhatun. 2008. Pengaruh Tangibility, Pertumbuhan Penjualan Dan Ukuran Perusahaan Terhadap Struktur Keuangan. Jurnal Bisnis Dan Akuntansi. Vol. 10. No. 1. Hal: 13-22.

Timbul, Yuandi K. 2013. Perputaran Modal Kerja Dalam Mengukur Tingkat Profitabilitas Pada Pt. Jasa Angkasa Semesta, Tbk. Jakarta. Jurnal EMBA. Vol.1. No.4. Hal: 134-140. 